日臨外会誌 $66(4), 842-847,2005$

症例

再発を繰り返した高齢者の上腸間膜動脈性十二指腸閉塞症の 1 例

健和会病院外科

本田晴康津澤豊一川田崇雄熊谷嘉隆

症例は71歳, 男性. 主訴は上腹部膨満とコーヒー残渣様嘔吐. 過去に同様のエピソー ドが 6 回あり，他院での保存的治療で軽快していた，2003年10月 6 日大量のコーヒー残 渣样煰吐を生じ当院初診入院, 誤㖟性肺炎を生じショックに至ったが回復した. 腹部 CT 検査で SMA 症候群が疑われたが, SMA の分岐角は $33^{\circ}$ とやや小さい程度であった。経過 良好で食後の体位変換を指導し32病日退院したが,11日目に再び同症状出現し入院した。 今回は 4 日間の保存的治療で軽快したが，短期間に再発し 8 回目であること，前回誤德 性肺炎を生じたことより手術適応と判断し，2003年12月16日十二指腸空腸側々吻合術を 行った。術後経過良好で体重が11 kg 増加した。再発を繰り返す例や重篤な合併症を併発 した例は手術の適応であり，十二指腸空腸吻合術は低侵襲で有効性の高い術式と思われ た。また高齢者では若年者に比し保存的治療が無効の場合が多く，手術を要することが 多い.

卖引用語：上腸間膜動脈性十二指腸閉塞症, 高齢者, 十二指腸空腸吻合術

\section{はじめに}

上腸間膜動脈性十二指腸閉塞症 (以下 SMA 症候群) は上腸間膜動脈 (以下 SMA) と脊椎や大動脈との間で 十二指腸第 3 部（水平脚）が圧迫され通過障害をきた す疾患である。

今回われわれは再発を繰り返した高榆者の慢性型 SMA 症候群を経験し, 十二指腸空腸吻合術を行って 良好な経験が得られたので,70歳以上高齢者の本邦報 告例を集計し，本症に対する手術適応，手術法などに つき検討した。

\section{症例}

症例: 71歳, 男性.

主訴: コーヒ一残渣様嘔吐.

家族歴・既往歴：特記すべきことなし．

現病歴：1996年より嘔吐, 吐血で他院に 6 回の入院 歴あり。最終退院は2003年 9 月12日. 同院では「逆流 性食道炎」との説明を受け，オメプラゾール，クエン 酸モサプリドの処方を受けていた。 2003年10月 5 日22 時頃より突然コーヒー残渣様嘔吐が頻回に出現したた

2004 年10月22日受付 2005 年 2 月 8 日採用 〈所属施設住所〉

テ395-8522 飯田市鼎中平 1936
め, 10 月 6 日当院初診, 入院となった。

入院時現症：身長 $161 \mathrm{~cm}$, 体重 $43 \mathrm{~kg}$ (肥満度 : -24 $\%)$. 体温 $37.1^{\circ} \mathrm{C}$. 血圧 $134 / 78 \mathrm{mmHg}$. 脈拍 $70 /$ 分. 呼 吸音整。腹部膨满著明だが，圧痛なく，腹膜刺激症状 も認められなかった。

入院時検查所見 : BUN が $27.8 \mathrm{mg} / \mathrm{dl}$ とやや高値て あった以外, 異常は認められなかった。

上部消化管内視鏡検査: 褐色の胃液が大量に貯留 し,約2L を吸引した.十二指腸下行脚には残湐が多く, これより先の観察は不可能であった。また出血を伴う 逆流性食道炎が認められた。

画像所見：腹部X線（立位）検査で胃および十二指 腸上部に鏡面像が形成 (double bubble sign) されて いた。腹部 CT 検査では胃から十二指腸水平脚までの 拡張が著明であったが, 小腸, 大腸の拡張は認められ なかった（図 1 )。寛解期に施行した十二指腸造影検査 (上部消化管内視鏡下) では十二指腸水平脚に器質的 な狭乍はなく，通過は良好であった（図 2）。

入院後経過：経鼻胃管による胃内減圧処置を行った が, 10月 7 日 $39.8^{\circ} \mathrm{C}$ 発熱とともに血圧が低下 $(64 / 40$ $\mathrm{mmHg}$ ), 脈拍微弱となり, $\mathrm{SpO}_{2} 62 \%$ と低下した。誤 蠉性肺炎から敗血症性ショックに至ったと診断し, 酸 素投与，抗生㓮・昇圧㓮投与などの治療を行った。全 


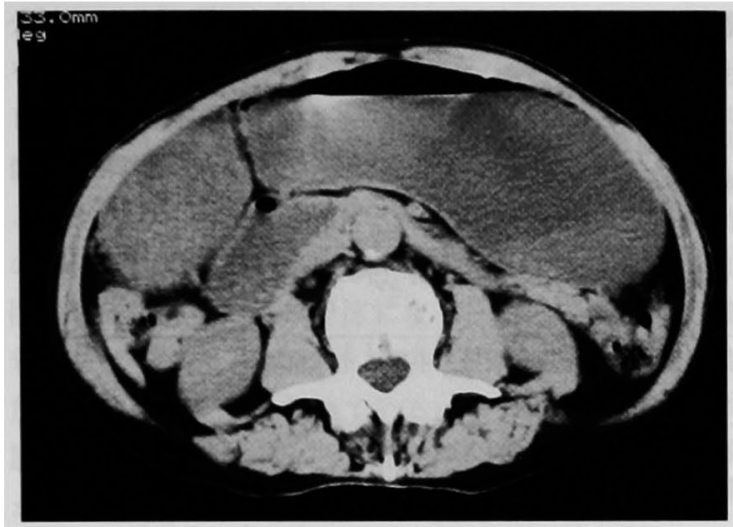

図 1 腹部 CT 検查（入院時）：胃から十二指腸水平脚ま での拡張が著明であったが, 小腸, 大腸の应張は認めら れなかった。

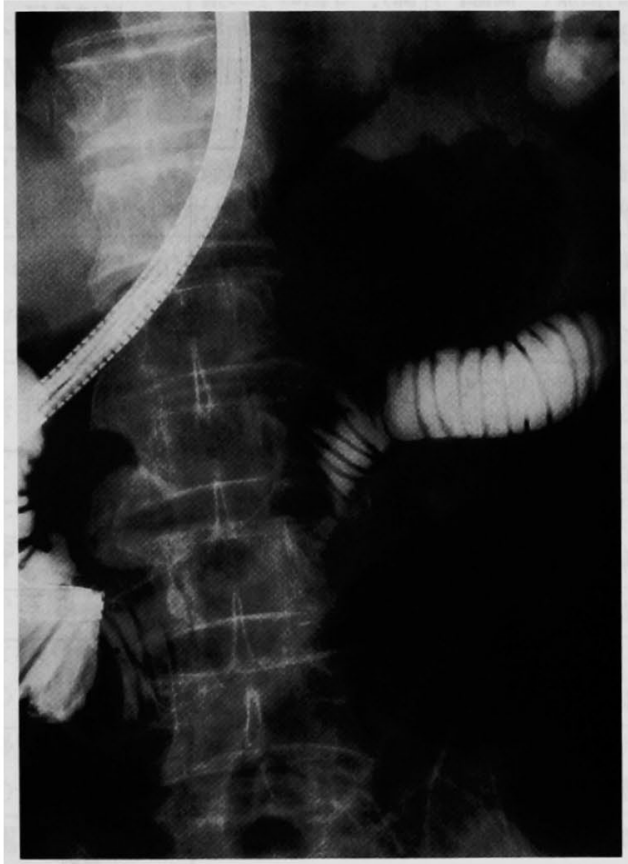

図 2 十二指腸造影検査（上部 消 化管内 視 鏡 下)：寬解期に施行した検査では十二指腸水平 脚に器質的な狭窄なく，通過良好であった。

身状態改善し，12病日より経口搷取開始，食後の体位 変換（腹臥位, 胸滕位, 左側臥位）など行いながら以 後順調に経過した。腹部 CT 検查により SMA 症候群 が疑われたが, MRI で計測したSMAの大動脈との分 岐角 (aortomesenteric angle, 以下 AMA) は $33^{\circ}$ と正 常よりやや小さい程度であった(図 3 ). 経過良好であ ったので過食を避けること, 食後の体位変換などを指
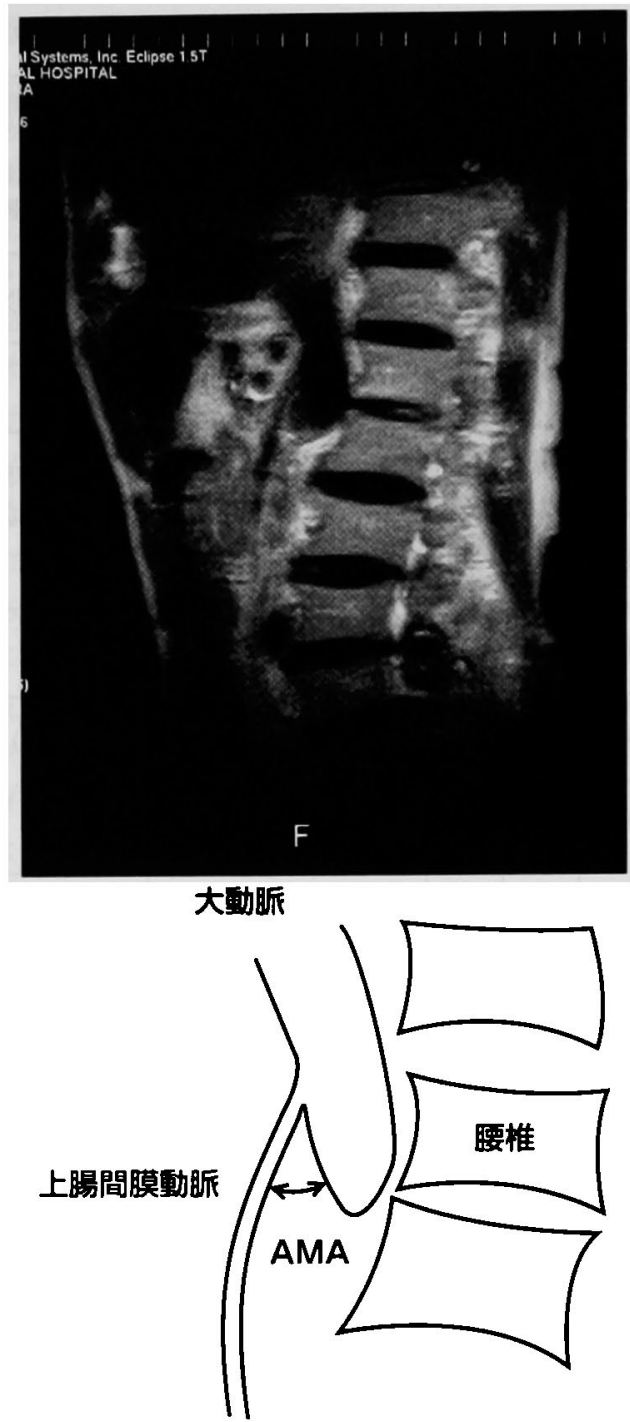

図 3 MRI 検査およびシェーマ：SMA の大 動 脈との分岐角は $33^{\circ}$ と正常よりやや小さい程度 であった。

導し11月 6 日（32病日）退院となった。

ところが退院後11日目に再び同症状出現し，再入院 した。今回は 4 日間の保存的治療で軽快したが，短期 間の内に再発し，8回目のエピソードであり，前回入 院時には誤舆性肺炎を生じショックに至ったことより 手術適応と判断し，12月16日手術を施行した。

手術所見：上腹部正中切開で開腹. 大網，腸間膜な どの脂肪織は極めて少なかった。 十二指腸，脺頭部に は通過障害をきたすような病変は認められなかった。 横行結腸間膜右側を開空し，十二指腸第 3 部と Treitz 
表 170 歳以上高橉者の SMA 症候群本邦報告例（1995年以降）

\begin{tabular}{|c|c|c|c|c|c|c|}
\hline 報告者 & 年龄 & 性別 & 既往歴・誘图 & 画像所見 & 治潦法 & 予後 \\
\hline 山元 ${ }^{24}$ & 86 & वे & $?$ & $\begin{array}{l}\mathrm{CT}: \text { 門脈内ガス, } \\
\text { 十二指腸壁内ガス }\end{array}$ & 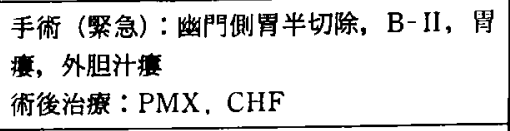 & 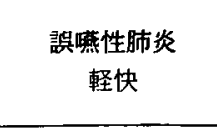 \\
\hline 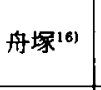 & 77 & $\sigma$ & $\begin{array}{l}\text { 長期卧床 (CHF，Par- } \\
\text { kinson) }\end{array}$ & AMA (US) $: 12^{\circ}$ & $\begin{array}{l}5 \text { 日間の保存的治療後, 手術：十二指腸空 } \\
\text { 腸側々吻合術 }\end{array}$ & 良好 \\
\hline 渡部 ${ }^{22)}$ & 74 & + & $\begin{array}{l}\text { 腹部大動脈瘤・人工血 } \\
\text { 管置換術後 }\end{array}$ & & $\begin{array}{l}\text { 約 } 3 \text { 週間の保存的治療後, 手術：十二指腸 } \\
\text { 空腸側々吻合術 }\end{array}$ & 良好 \\
\hline 吉川 & 78 & q & $?$ & AMA(US) : 51 & $\begin{array}{l}\text { 約 } 2 \text { 力月間の保存的治療後, 手術：十二指 } \\
\text { 腸空腸移動術, 挟窄部切除 }\end{array}$ & 良好 \\
\hline 藤田 ${ }^{171}$ & 70 & $\sigma^{x}$ & $\begin{array}{l}\text { 長期臥床（眠瘦末期状 } \\
\text { 態） }\end{array}$ & & $\begin{array}{l}\text { 約 } 2 \text { 力月間の保存的治療後, 手術：腸回転 } \\
\text { 解除術 }\end{array}$ & 良好 \\
\hline 錕(山19) & 74 & 8 & 大腸癌手術 $\rightarrow$ 疮着 & & $\begin{array}{l}\text { 約 } 2 \text { 週間の保存的治療後, 手術：胃空腸吻 } \\
\text { 合術 }\end{array}$ & 良好 \\
\hline (承東” & 87 & $\sigma^{7}$ & 過食？ & AMA (US)：鋭角化 & $\begin{array}{l}\text { 保存的治療 (〔高龄, 片肺). } 3 \text { 回の十二指 } \\
\text { 腸閉塞症状 }\end{array}$ & ほほ良好 \\
\hline 河内" & 84 & का & $\begin{array}{l}\text { 胆摘街後 } 10 \mathrm{~kg} \text { の体重 } \\
\text { 減少 }\end{array}$ & & 手術: Treitz勒带切離, 索状物切除 & 良好 \\
\hline 初貝 & 80 & $\sigma^{\pi}$ & 腹部大動脈瘤 & & $\begin{array}{l}\text { 約 } 7 \text { 週間の保存的治療後, 手術: 十二指腸 } \\
\text { 空腸側々吻合術 }\end{array}$ & 良好 \\
\hline 山川|'3! & 80 & + & $\begin{array}{l}\text { アルツハイマー型老年 } \\
\text { 痴呆 }\end{array}$ & & $\begin{array}{l}\text { 保存的治㙩効果なく, 手術拒否のため内視 } \\
\text { 鏡的胃㿉設術を応用して空腸チューフから } \\
\text { 経腸栄䔲 }\end{array}$ & 安定 \\
\hline 高橋 & 74 & 8 & $\begin{array}{l}\text { 肺癌胸壁転移放射線治 } \\
\text { 療後 }\end{array}$ & & 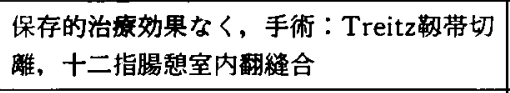 & 良好 \\
\hline 上竹 & 72 & 8 & 瘦せ型 & & 保存的治療 & 良好 \\
\hline 木田 ${ }^{18)}$ & 83 & 8 & $\begin{array}{l}\text { 感冒による䕕たきり， } \\
\text { 食事搨取不良 }\end{array}$ & & $\begin{array}{l}\text { 約 } 3 \text { 力月間の保存的治療後, 手術：十二指 } \\
\text { 腸空晹側々吻合術, 胃瘦 }\end{array}$ & 誤噮性肺炎で死亡 \\
\hline 永井 & 76 & $\sigma^{7}$ & 肺結核に上る慢性脤胸 & & 保存的治療（大呼吸器合併症） & 軽快 \\
\hline 萧高 ${ }^{23)}$ & 75 & + & $\begin{array}{l}\text { 腹部大動脈瘤. } 10 \mathrm{~kg} の \\
\text { 体重隇少 }\end{array}$ & AMA $: 17$ & $\begin{array}{l}\text { 手術：十二指腸授動術, 動脈瘤切除・人工 } \\
\text { 血管置換術 }\end{array}$ & 良好 \\
\hline 萧高 ${ }^{23)}$ & 72 & $\sigma^{7}$ & 腹部大動脈瘤 & AMA : 15 & $\begin{array}{l}\text { 手術：十二指腸授動術, 動脈瘤切除·人工 } \\
\text { 血管置換術 }\end{array}$ & 良好 \\
\hline 大月 & 76 & 0 & $\begin{array}{l}\text { 腹部大動脈瘤・人工血 } \\
\text { 管置換術後 }\end{array}$ & & $\begin{array}{l}2 \text { 週間の保存的治療後, 手術：十二指儤空 } \\
\text { 腸側々吻合術 }\end{array}$ & 良好 \\
\hline 古川| $\left.\right|^{21\}}$ & 76 & 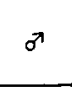 & 直腸癌術後, 肺癌術後 & AMA (US)：狭小化 & $\begin{array}{l}\text { 13日間の保存的治療後, 手術：十二指腸空 } \\
\text { 腸側、吻合術 }\end{array}$ & 気管切開, 良好 \\
\hline 小野 & 76 & $\sigma^{7}$ & $\begin{array}{l}\text { 大腸癌術後 } 14 \mathrm{~kg} の \text { 体 } \\
\text { 重隇少 }\end{array}$ & $\operatorname{AMA}(\mathrm{CT}): 30^{\circ}$ & 保存的治療 & 良好 \\
\hline 自験例 & 71 & 8 & 慢性型 & AMA (MRI) $: 33^{\circ}$ & 手術：十二指腸空腸側々吻合術 & 良好 \\
\hline
\end{tabular}

靶帯より $15 \mathrm{~cm}$ の空腸を側々吻合した。

術後経過：良好で術後6日目の造影検査では, 吻合 部の通過は良好で,また造影剤は順行性に Treitz 靶帯 を経由しても流れた。経口摄取は順調に進み術後25日
目に退院した。術後10力月現在, 経過良好で体重も11 $\mathrm{kg}$ 增加した。

\section{考察}

SMA 症候群は十二指腸第 3 部 (水平脚) が SMA の 
分岐部近くで腸間膜根によって圧迫されて高位腸閉塞 をきたしたものと定義される。瘦せ型の人に多く発症 し, 胆汁性哣吐を主訴とし，ときに Mallory Weiss 症 候群や消化性謴場を合併する。発生機序として SMA と大動脈の狭角度や高位十二指腸, 短 Treitz 鞄帯など の解剖学的異常に加え, 低栄湌などによる十二指腸周 囲脂肪織の減少, 長期臥床による圧迫, 手術操作や痹 着など(12)による腸間膜の下方への㐮引などの誘因が 加わって発症するとされている，自験例は過食などの 誘因もなく突然発症し, 保存的治療により比較的速や かに軽快していた. 繰り返すエピソードのため肥満度 はー24\%とるい瘦を認め, 体重減少のため腸間膜根部 の脂肪織がさらに減少し症状が増悪するという悪循環 を形成していたと思われる，詳細は不明であるか，患 者は“逆流性食道炎” と説明されており, 他院担当医 に本症の認識がなかったと思われる。

SMA 症候群の診断は前述の臨床症状に加えて, 腹 部単純X線検査に扔ける胃拡張と十二指腸球部の拡張 による double bubble sign，上部消化管造影検查にお ける十二指腸水平脚での直線的断裂狭窄 (straight line obstruction), 造影剂の振り子様蠕動 (to-and-fro movement）があれば容易である. また超音波 ${ }^{3) 4, ~ 3 D ~}$ $-\mathrm{CT}^{5,6)}$, MRI 検査などによる AMA の測定も有用な 診断手段とされ, 正常では45〜65であるが, SMA 症候 群では $20^{\circ}$ 以下とされている7゙. 自験例は寛解期に行っ た上部消化管造影検查では上記のような特徵的な所見 は得られず，MRIての測定では AMA は33とやや小 さい程度であり，保存的治療がそれなりに奏効して再 発を繰り返す慢性型であった。最近では発症時と改善 時の AMA に差がないこと，狭角度であっても SMA の移動性が大きければ発症しないことなどより, 角度 そのものより SMAによる十二指腸の圧迫とそれに伴 う運動低下を発症の要因とする報告が見受けられ $3^{388)}$.

SMA 症候群の治療法としてはまず内科的治療が選 択されるが，その期間は報告者によって様々であり， 3 カ月間の中心静脈栄養で治瘾したとの報告"ももる が, 概ね $2 \sim 3$ 週間程度とするものが多い(10)! 若年者 や腹部手術の既往のないものは症状も可逆性であり, 食後の体位変換や中心静脈栄養, あるいは狭窄部を越 えてのチューブフィーディング(2)13)などの治療が奏効 している。一方, 外科的治療に関しては内科的治療に 抵抗する症例や腹部手術の既往があり, 術後の瘑着を 原因とする場合 ${ }^{122)}$, あるいは自験例のように再発を繰
り返す例，重篤な合併症を併発した例が手術適応と考 えられている．どの時点で手術療法へ踏み切るべきか は見解の一致をみておらず，特に成長期にある小児で はSMA 症候群が一時的なものである可能性もあり， 判定が難しい.しかし高齢者ては再発を繰り返すこと が多く，手術を要することが多い(4).

SMA 症候群の手術法を大別すると，1）十二指腸空 晹吻合術, 胃空腸吻合術などのパイパス術，2) Treitz 勒带切離術, 十二指腸・空腸・結腸授動術, 腸回転解 除術などの授動術，3）十二指腸前方転位術，4）上 腸間膜動脈前方挙上術 ${ }^{(5)}$ の 4 つがある。横井ら ${ }^{14)}$ の本 邦101例の集計では十二指腸空腸吻合術が75\%, 授動術 が15\%，十二指腸前方転位術が10\%に施行されている。 十二指腸前方転位術は再建経路が生理的であり, 本症 の成立機転を最も考虑した術式とされているが手技が やや煩雑であり，授動術は瘜着による再閉塞”により 治療効果が不安定とされている。十二指腸空腸吻合術 では blind loop 症候群の発生が危惧され, 根治的では ないものの, 手技が容易で比較的侵襲が少なく, 報告 例では経過は極めて良好である。自験例も十二指腸空 腸側々吻合術を採用したが, 術後造影検查では造影䨩 は主にはバイパスを経由して流れたが，一部は順行性 に Treitz 勒帯を経ても流れるのを確認でき，現時点で は blind loop 症候群の症状は認められない.したがっ て経験の少ない中，緊急手術や高齢者手術など手術侵 襲を極力避けたい場合には十二指腸空腸吻合術は低侵 裝で有効性の高い術式と思われる.

さて SMA 症候群は10～30歳の若年者に多いと報告 されている(10)14)が, 最近では70歳を超えた高齢者の報 告も散見されるようになり，若年者とはその誘因や状 況も異なり，したがって治療法および手術適応なども 異なると推測されるので，70歳以上高齢者の本邦報告 例を集計し考察した. 1995年以降で詳細の明らかな70 歳以上 SMA 症候群報告例は自験例を含めて20例であ った (表 1 ). 最高齢は87歳で, 男性16例女性 4 例と男 性に多く認められた。誘因が明らかなものは12例で長 期臥床 3 例 ${ }^{16)-18)}$, 術後 (痹着, 体重減少) 6 例1119) -22), 腹部大動脈瘤 3 例23)であった。 AMAについては記載 のある 8 例のうち鋭角化は 6 例(416)21123)であった。治療 法は手術適応と考えられた16例のうち家族が手術を拒 否したアルツハイマー型痴呆例 ${ }^{33}$ を除く 15 例, $79 \%$ で 手術が行われて扔り，この内 4 例は 7 週から 3 力月間 の保存的治療が奏効せず(7)18)201, 手術を要している。 た術式はバイパス術 8 例, 授動術 6 例, 胃切除 (B-II) 
1 例で十二指腸前方転位術を採用したものはなかっ た。術後経過は 2 例 ${ }^{1824)}$ が䛇㑤性肺炎を生じ,この内 1 例18)が死亡しているが，他の13例は良好である.以上の 結果より高齢者においては保存的治療を行いつつも比 較的早期に手術適応を判断し, 授動術, 十二指腸空腸 吻合術などの低侵㜔な術式を選択すべきと思われる。

\section{結語}

1.再発を繰り返した高齢者の上腸間膜動脈性十二 指腸閉塞症例を経験した.

2.自験例のように再発を繰り返す場合や重篤な合 併症を併発するものは手術の適応と思われる。

3. 高齢者では小児や若年者に比し保存的治療が無 効の場合が多く，手術を要することが多い.

4. 十二指腸空腸吻合術は低侵襲で有効性の高い術 式と思われた。

なお, 本論文の要旨は第66回日本臨床外科学会総会(盛岡 市）において発表した。

\section{文 献}

1）河内和宏, 沖田光昭, 繁本茂憲: 空腸瘾着性イレ ウスによる上腸間膜動脈症候群の 1 例。日臨外会 誌 $56: 375-378,1995$

2）濱崎達憲, 森 尚秀, 和田守慧二他：直晹癌手術 後に上腸間膜動脈症候群をきたした 1 例. 日消外 会誌 32：2689-2693，1999

3）辻 高明：超音波断層法による上腸間膜動脈の 観察。日整外会誌 61：1047-1057，1987

4) 伊東友弘, 高橋正一郎, 小川正純他：腹部超音波 検查が䛦断に有用であった上腸間膜動脈症候群の 1 例. J Med Ultrasonics 25:1067-1072, 1998

5）原敬, 篠田康夫, 飯塚正二他：三次元 CT 診断に有用であった上腸間膜動脈性十二指腸閉塞 症の 1 治験例。外科治療 $83: 249-251,2000$

6）芝原一繁，尾山佳永子, 荒能義彦他：十二指腸転 位術が奏功した上腸間膜動脈应候群の 1 例。臨外 $56: 255-258,2001$

7) Mansberger AR Jr, Hearn JB, Byers RM, et al: Vascular compression of the duodenum; emphasis on accurate dignosis. Am J Surg 115 : 89-96, 1968

8）大野耕一, 森内隆喜, 中岡達雄地：学童に発症し た上腸間膜動脈性十二指腸閉塞症の 1 例. 小坚科 $37: 1087-1090,1996$

9）鎌田政博, 西 猛, 神野和彦他：3力月間の中 心静脈栄養により治傯した上腸間膜動脈症候群の
1 例。小览診療 $53 ： 352-356 ， 1990$

10）土岐 彰、戸谷拓二, 渡辺泰宏他：上腸間膜動脈 症候群の 3 例と本邦例の統計的考察. 日小唯外会 誌 $24: 110-115,1988$

11）森 昭文, 山崎 修, 李 光春他：上腸間膜動脈 性十二指腸閉塞症の 1 手術例. 日臨外会誌 54 ： 967-972, 1993

12）菊池 透, 田中雅昭, 内谷 哲：いわゆる「ダイ エット」を契機に発症した上腸間膜動脈症候群の 1 例。小坚臨 $47: 149-154,1994$

13）山川 治, 古澤明彦, 中源雅佁: 内視鏡的胃㩲造 設術を応用して長期栄養管理を試みた高龄者上腸 間膜動脈性十二指腸閉塞症の 1 例. Endosc Forum digest dis $12: 320,1996$

14）横井公良, 森山雄吉, 京野昭二他：前方転位術を 施行した高齢者上腸間膜動脈症候群の 1 例. 日臨 外会誌 $58: 2574-2579,1997$

15）太田 保, 平松 聡, 森崎 太他：上腸間膜動脈 性十二指腸閉塞症に対する大網による上腸間膜動 脈前方挙上法。手術 $51: 2181-2184 ， 1997$

16）舟塚雅英, 佐藤仁俊, 小野恵司他：早期手術が有 奻であった高龄者上腸間膜動脈性十二指晹閉塞症 の1例. 日臨外会誌 $63: 1429-1433,2002$

17）藤田秀人, 薮下和久, 山本精一他：腸回転解除術 を施行した上腸間膜動脈症候群の 1 手術例. 手術 $56: 101-104,2002$

18）木田睦士，金子 崺，武鏠豊文他：上腸間膜動脈 症候群の 2例. 豊岡病紀 14:5-8, 2002

19）錧山秀人, 新田 貢, 松下第一：左半結腸切除術 後に発症した上腸間膜動脈症候群の 1 例。日臨外 会誌 $61: 181-185,2000$

20）古川 浩, 多田哲也, 桑原史郎他：胃穿孔をきた した上腸間膜動脈性十二指腸閉塞症の 1 例。日臨 外会誌 $61 ： 1775-1779,2000$

21）古川義英, 八島 玲, 門馬智之他：上腸間膜動脈 症候群の 1 例。太因病年報 $37: 11-15,2002$

22）渡部宜久, 原田直樹, 中桐啓太郎他：腹部大動脈 瘤術後に発生した十二指腸閉塞の 1 手術治験例。 外科診療 $37: 1379-1382,1995$

23）兼高武仁, 小山博之, 重松 宏: 腹部大動脈瘤に よる上腸間膜動脈症候群（SMAS）の 2 手術例. 日消外会詰 $34: 1223,2001$

24）山元英資，河崎秀樹，井上 仁他：門脈ガス血症 をきたした上晹間膜動脈症候群の 1 例。愛媛病会 誌 $37: 49-52,2001$ 


\title{
A CASE OF RECURRENT SUPERIOR MESENTERIC DUODENAL OBSTRUCTION IN AN ELDERLY PATIENT -A STUDY OF DOMESTIC CASES OVER 70 YEARS OLD-
}

\author{
Haruyasu HONDA, Toyokazu TUZAWA, Takao KAWADA and Yoshitaka KUMAGAI \\ Department of Surgery, Kenwakai Hospital
}

A 71-year-old emaciated man was admitted to the hospital because of upper abdominal distension and hematemesis. He had had six episodes of these symptoms which had been treated conservatively at another hospital. Plain abdominal X-ray and CT scan suggested superior mesenteric duodenal obstruction. Conservative therapy with postural changes and nasogastric tube drainage was started, but 2 days later septic shock because of aspiration pneumonia occurred. He recovered by intensive care and his symptoms improved conservatively. He was discharged on the 32 nd hospital day, but 11 days later he was admitted to the hospital again because of the same symptoms. This time symptomatic remission could be attained with 4-day conservative treatment. We thought, however, that he was a candidate for operation because this was $8^{\text {th }}$ episode recurred in a short time after the former episode and he had aspiration pneumonia at the former episode. We performed a side to side duodenojejunostomy. The postoperative course was uneventful and ten months later he gained $11 \mathrm{~kg}$ in weight. It is thought that recurrent cases or serious cases of the disease with complications should be indicated operation, and duodenojejunostomy is a minimal invasive and useful procedure. Compared with younger patients, elderly patients do not respond well to conservative therapy and require surgical operation in many cases. 